DOI: $10.15503 /$ jecs20141-28-40

\title{
ENVIRONMENTAL ATTITUDES AND ECOLOGICAL ANTHROPOCENTRISM: A NEW CHALLENGE IN ENVIRONMENTAL HIGHER EDUCATION
}

\author{
ATTILA MIKLÓs, PHD \\ Faculty of Economics and Social Sciences, Szent István University, \\ 1 Páter Károly str., H-2100 Gödöllő, Hungary \\ E-mail address: miklosattila82@gmail.com

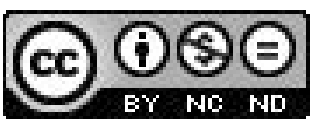

\begin{abstract}
The human-centric nature of environmental thinking is a highly successful adaptation, which has biological, historical, cultural origins. The dichotomy of anthropocentrism and ecocentrism are what ultimately determine ecological attitudes. This nationally representative study presents how students in Hungarian environmental education bachelor programs view the human's taxonomic position in the world (hierarchies, kinship), throughout evolution (determining possible directions, distancing from other organisms), the role of human power, and our rights of intervention in the environment. It shows what kind of knowledge students arrive with from public education, how they think about handling conflicts, and what impact their acquired knowledge during university years has on their environmental attitudes. It was found that at least two-thirds of students evaluated natural environmental processes, problemsand their consequences with anthropocentric preferences - in contrast to scientifically accepted theses.
\end{abstract}

Key words: environmental attitudes, anthropocentrism, evolutionary thinking, sustainability, ecological systems

\section{INTRODUCTION}

Environmental thinking is a defining element of our everyday lives, our decisions and actions. Thus its development is a major priority of environmental and education policy. The primary intention of public policy and related measures is typically to improve people's everyday lives, but often this leads to ignorance towards the interests of ecological sustainability, the safety requirements of naturally occurring processes. There are also major problems in the area of environmental research (regarding the applicability of the results) because most of them are relatively satisfied with reaching superficial conclusions: the context, the deeply hidden (and sometimes radical) conceptions and misconceptions are often not explored.

The current public perception is that the role of environmental education would be to enlighten and activate environmentally conscious citizens who have 
a broadview and responsible thinking about current and future climate issues. In order to achieve this aim students are required to learn basic principles such as risk minimization, prevention, damage control, self-improvement, with a systematic approach to ecological thinking. However, in public education teachers need to face many risks and challenges in their own environmental teaching processes day after day, in the world of the higher education the primary risk is the beginning itself: the total lack of education for sustainable development.

Institutional decentralization and inefficient implementation of adult pedagogy constitutes a similar obstacle: the first usually entails excessive facultative approaches (unique management approaches, total academic freedom) while the second implies a rejection of educational tasks that gauge the success of environmental awareness-raising based on personal initiatives of the individual. The situation is further complicated by the fact that in this system there are no built-in guarantees or reward for achieving environmental competencies and attitudes.

The results of the polls may be instructive for deeper environmental studies. Szántó (1994) describes four types of environmental worldview as 'practical approach'; 'mild ecocentric world view'; 'stronger ecocentric world view' and 'technical optimism'. He refers that religion may has important role in the type of environmental attitudes. In Hungary, the most common view is 'practical approach' and the least prevalent is 'stronger ecocentric world view'. The former group is only interested in solving specific problems, while the latter emphasizes the preciousness of nature. In opinion of 'technical optimistic' group people have right to use nature for well-being and technology will solve all the environmental problems. However, 'mild ecocentric world view' group makes the technology and economy responsible for degradation.

Kellert (1976) categorizes the American society's environmental thinking on the basis of other criteria. He defines 'attitude types' and the members of groups in his system relate to animals as 'naturalists', 'ecologists', 'humanists', 'moralists', 'scientists', 'aesthetics', 'utilitarians', 'doministics' and 'negativistic people' depending on the aim what orients them. All categories concentrate to show positive or negative attitudes (calculating with neutrality and indifference as well).

Havas \& Varga (1998) writes that an environmental attitude is positive when people care about environment and are interested in impacts of activities and try to minimize the negative environmental effects. However, this research tries to discuss the view that the negative environmental attitudes are just mindsets when people do not care about environment or are not interested in the problems of environment (passivity). Of course, it's difficult to imagine that someone intentionally wants to destruct the environment (particularly the natural environment), consequently we understand the logic of original definition of negative environmental attitudes. But if we look some detail questions, we can see differences between positive (but 'passive') and negative (and 'active') attitudes (for example, if we are talking about the general respect of nature and during this time we have distressful reviews about certain ",useless" or "harmful” organisms - and we need their destruction). It seems obvious that the majority of participants in the study are aware of what society's expectations in connection with most significant environmental problems, but there 
may be other hidden thoughts and on the subconscious level where we could find completely opposite opinions and theories as well.

Ecological, biological and environmental literacy are important parts of attitudes and basically bind to educational content and hard to define them like the concept of 'general knowledge'. Csapó (2002) writes that ecological literacy goes beyond the aims of immediate school's curriculum and includes the general awareness and ability of acquired knowledge in ecological process themes. The definition of environmental literacy is very similar to ecological literacy that goes beyond the "biological limit". We can find here the traces of anthropocentric environmental thinking and the contradictions with scientific thinking.

\section{ANTHROPOCENTRIC ATTITUDES}

One of the main feature of anthropocentric thinking is that it makes rigid views in the relationship between man and nature. Lányi (1999) says that opposite of antropocentrism is the deep ecological thinking. According to him, the deep ecology means the equality of living beings, so proponents of this paradigm reject any notion that people have privileged position in the living world. The anthropocentric environmental thinking primarily causes exclusion, even if we can not clearly link to particular world views or political views. It reflects an essentialist mindset so adds some unique attributes (characteristics) to human like a privilege. According to 'only Homo sapiens can communicate on high level', 'only has personality and emotions' and 'not only controlled by instincts' and 'not part of the fauna'.

Secondly, anthropocentrism causes teleological thinking, where every natural phenomenon, operational mechanism has an aim. Regarding to a study of Varga (2004) who carried out a research among children, shows that most of teenagers think that 'the cactus has ability to control in its body structure and therefore it grows spikes to defend itself against herbivores'.

Thirdly, the contradictory behavior can cause problems while human tries to make distance from nature, still anthropomorphize creatures, gives them human qualities and judge them like human beings. Thus, human thinking necessarily confronts scientific approaches because ecological thinking become unsustainable what only works well in human imagination.

Tamir and Zohar (1991) developed their hypothesis based on their experiences and showed that children have anthropomorphic ideas until old teenager period in connection with biological and ecological phenomena. The researchers make responsible for the wording of textbooks, the too anthropomorphic definitions, which can contribute the mindset. Mérei \& V. Binét (2006) explains that children thinking is characterized by anthropocentrism and their natural phenomena is already 'animated' so in this system the functioning of natural systems will be necessarily anthropomorphic. Southerland et al (2001) examined how students explain variety of biological phenomena and processes from early school age to the end of high school. From the interviews was found out that one in five respondents strongly anthropomorphized natural systems and almost half of students preferred the explicitly teleological explanations. 
Gould (1996) also draws attention to the fact that comparative psychology literature is full of hierarchy emphasizing phrases such as 'sub-human primates", 'mammals below primates' or 'vertebrates below mammalian'.

The study declares that the dichotomy of anthropocentrism and ecocentrism in environmental thinking is the greatest determining factor in ecological attitudes - and also the cause of the biggest problems. The human-centric nature of environmental thought is a highly successful adaptation that has biological, historical, cultural and moral origins -which of course do not have equal weight. Because every environmental-natural, especially biological and ecological issues are approached in accordance with its particular nature, the formation of the anthropocentric approach causes self-reflexively on the consciousness, the decisions, conclusions and views.With its highly adaptive nature this view usually manages to self-reinforce and confirm itself during environmental action. Of all of these perhaps the most serious consequence is the formation of rigid perspectives through socialization that shape environmental thinking and negative environmental attitudes. In addition, from earlier we also know that the anthropocentric perspective is a major obstacle of the ecological phenomena, systems and processes descriptions and modelling (Nevanpää \& Law, 2006).

Of course, we may rightfully ask why anthropocentrism is regarded as a problem. Primarily because this is an exclusionary view system, whether or not it is linked to any specific ideologies. It reflects a strong essentialist mind-set that only humans have certain characteristics, and this constitutes a privilege, which predestines him to direct intervention in natural processes. The existentialist philosopher Wolfgang Schirmacher - like Martin Heidegger - has long claimed that the authoritarian attitudes about nature, with humans at centre stage, can not be considered a kind of natural attitude, but are instead a distortion of civilization that can occur in any social system (Schirmacher, 1992).

Some typical manifestations of anthropocentric thinking are the assumptions that only Homo sapiens is capable of thinking, the only ones who can speak, the only ones with personality. Man is the sole creature who is not controlled only by its instincts and the one who can be meaningful. Many people also assume that humans are not part of the animal kingdom. Man is thus prone to significantly distance himself from nature and look for those aspects that reinforce and repeatedly confirm his assumptions. This helps form human self-reflections and role perceptions as the dominant and divine or other (see later in the "anthropocentrism inhomogeneity" chapter).

Anthropocentrism also thoroughly questions and gives much significance to whether it is possible at all for other living being's to possess personality, intelligence, emotions. Rankings are formed among creatures. The morphological similarities and differences, the putative genetic relationships between human beings and other organisms also play an important role. Thus in human-centric thinking these factors decide how we may feel responsible for the fate of the natural creatures and to whom we can say: "It's a lovable creature." Many living beings may derive some benefits from being similar to us in some respects or as they adapt to our human world and become good organisms. Others are simply cast as evil. 


\section{THE EMPIRICAL RESEARCH METHODOLOGY}

A written questionnaire-based attitudes-research - with questions directed towards the detection of anthropocentrism - examined and evaluated the university students' ecological and scientific literacy, logic skills within the themes of evolution and other conceptual knowledge. I managed to uncover how they see the role of humans and their taxonomic place in the living world (hierarchies, kinship degrees), in evolution (determine possible directions, distancing from other organisms), the role of human power, rights of intervention in the environment. The anthropocentric behaviour cannot be explained simply on the instinctual level of personality's components, because this works also on the ego and superego levels - including the adaptation and morality (Abel, 1989).This means that the human-centricbehaviour is not considered only a biologically determined (and therefore acceptable) problem, but also an integral part of a dynamic personality that can be developed - and clearly traceable through the attitudes.

The research aims to examine what kind of knowledge the environmental bachelor students who freshly arrived from the public education have, how they view their own relationship with the environment, how they handle conflicts and whether or not their acquired knowledge has positive impact on the environmental attitudes during college years.

I managed to do the sampling in 10 faculties of 7 higher education institutes, with the participation of 510 students (the population can be made $2500-4000$ per capita during this period). I examined four specific, explicitly environmental BSc fields of study (environmental engineer, environmental agricultural engineer, ecological engineering, environmental studies) where students can learn directly from the environmental profession. In the preparation process of the questions not only did it become quickly apparent that for the measurement of environmental attitudes using a Likert scale may be appropriate (especially if additional elaborative issues also appear in the questionnaire), but having regard to the magnitude of the problem and because of the requirement of proper context, I had to create logically related groups of questions. So it can be displayed (separately and holistically) the analysis of evolution, relationships, kinships, personality, loveliness, hierarchical views and human power reflexes. These groups can quickly and easily be attached to the background variables and other aspects as well: such as gender, age groups, educational grades, programs, institutions, and to any roles that affect the ecological literacy. During the evaluation I took into consideration 151 variables, so I worked up more than 77 thousand answers. The statistical software was SPSS 13.0 and during the evaluation I applied frequency, scattering investigation, correlation analysis, Mann-Whitney and Kruskal-Wallis tests etc. and for the detailed results I also used comparative analyses with smaller groups (formed by the previously described basis of background variables).

\section{RESULTS OF THE RESEARCH}

Taking into account all the results it can be stated that at least two-thirds of the students evaluated the natural environmental processes, problems and their consequences with anthropocentric preferences in opposition to the scientifically accepted 
theses and only a very small minority group represents a specifically nature-centred view. It has become clear that the unsustainable modes of society's operations have reflected in the students' ecological literacy. In connection with the general environmental issues the higher proportion of students produced relatively good results, however, the lowest environmental awareness level could be measured in relation to specific solutions (and American empirical studies conducted among engineering students reported very similar results: Dyehouse et al., 2011).

The research detected highly emotional attitudes - for example, the instinctual but functioning such as the conditional disgust reflex that manifests itself in the denial of being relatives with a flatworm or a cockroach - which will become an indirect part of the attitudes; or the fear impact which will become an indirect part of judging of each group of animals, where dangerous styled creatures are given a negative role. In addition, there were contradictions between the theoretical statements and the specific action intentions - for example, between the stated preferences versus actual participation in environmental investments; or own pets preferences against all other living beings, including the questioning of the personality of other organisms).

In general the denial of kinship with other living beings was typical with students' most apparent aversions towards the invertebrate. The students with higher level of general and professional education considered the environmental issues with less anthropocentrism and allowed themselves much closer to individual organisms (for example, in the kinship, personality, amiability themes).

Development skills and positivity of environmental attitudes did not increase during the years in higher education - as opposed to similar research results found in international literature. One important example is a Slovenian study that explored the ideas of students about water and water pollution and that their level of knowledge, conceptualization skills developed during the time spent in school (Rebolj \& Devetak, 2013). Similar findings were reported in connection with the development of biological thought in an Australian study, where the author suggested more efficient integration of evolutionary, ecological, genetic and cell biological knowledge to the existing procedures (Werth, 2013). In addition, the results of applied research in higher education have confirmed the fact that the success of the intervention is not hopeless. For example, a Canadian study showed that the problems of ecological approach were due primarily to the incomplete or misunderstood conceptual knowledge that came from high school, but significant improvement can be achieved using remedial courses in higher education (Puk \& Stibbards, 2011). Finally, a Hungarian research envisages similar developments such that newly arrived students could write a so-called criterion essay, and based on the results trainers could carry out remedial activities with needy students focusing on the supplement of gaps (Radnóti, 2009).

However, it should be stated that these measurements and interventions were optional and unique, so they did not demonstrate the usefulness of time spent in higher education but instead the effectiveness of specific interventions. Moreover, they do not confute that the in-depth and successful attitude and awareness raising can only be achieved by means of conceptual change and self-reflection, so 
the therapy of anthropocentrism is a very complex educational task that can not be achieved in the context of a recovery program.

The following table shows ten typical - in terms of the results of the research examples seeking to demonstrate that a significant part of environmental higher education students prefer the anthropocentric solutions and answers in relation to certain environmental matters. The research contains almost 100 similar Likert-scaled statements and works with 151 variables. The averages over four points clearly demonstrate that half of the respondents question the natural interests and the averages over three points demonstrate that the majority of students are uncertain or have specifically human-centric thinking. It also turns out that response tendencies of the freshman (input) and senior grades (output) students differ little, so the time spent (at least three years) at university does almost nothing to change the biological, ecological, or evolutionary thinking ( $\Delta$ (output-input) $<5 \%)$.

Table 1. Examples of student responses in various environmental issues ${ }^{1}$.

\begin{tabular}{|c|c|c|c|c|c|c|c|c|}
\hline $\begin{array}{c}\text { state- } \\
\text { ment } \\
\text { No. }\end{array}$ & \multicolumn{3}{|c|}{ input (N=228) } & \multicolumn{3}{c|}{ output (N=282) } & \multicolumn{2}{c|}{ output-input } \\
\cline { 2 - 10 } & mmean & $\begin{array}{c}\text { frequency of } \\
\text { anthropocen- } \\
\text { tric answers } \\
(\%)\end{array}$ & $\begin{array}{c}\text { standard } \\
\text { deviation }\end{array}$ & mmean & $\begin{array}{c}\text { frequency of } \\
\text { anthropocen- } \\
\text { tric answers } \\
(\%)\end{array}$ & $\begin{array}{c}\text { standard } \\
\text { deviation }\end{array}$ & $\Delta($ mean) & $\Delta(\%)$ \\
\hline 01 & 2.90 & 48.2 & 1.311 & 2.97 & 49.3 & 1.360 & 0.07 & 1.40 \\
\hline 02 & 2.76 & 50.9 & 1.296 & 2.94 & 44.0 & 1.282 & 0.18 & 3.60 \\
\hline 03 & 4.05 & 15.4 & 1.190 & 3.93 & 20.9 & 1.302 & -0.12 & -2.40 \\
\hline 04 & 3.42 & 35.5 & 1.495 & 3.41 & 34.8 & 1.474 & -0.01 & -0.20 \\
\hline 05 & 3.09 & 45.2 & 1.455 & 3.18 & 44.0 & 1.407 & 0.09 & 1.80 \\
\hline 06 & 2.20 & 73.2 & 1.263 & 2.47 & 64.2 & 1.305 & 0.27 & 5.40 \\
\hline 07 & 3.81 & 13.2 & 1.194 & 3.87 & 12.4 & 1.114 & 0.06 & 1.20 \\
\hline 08 & 1.93 & 71.1 & 1.202 & 2.07 & 61.0 & 1.188 & 0.14 & 2.80 \\
\hline 09 & 3.06 & 39.9 & 1.518 & 3.31 & 31.9 & 1.424 & 0.25 & 5.00 \\
\hline 10 & 3.20 & 42.5 & 1.318 & 3.18 & 41.5 & 1.314 & -0.02 & -0.40 \\
\hline
\end{tabular}

Source: answers of 510 students in 10 environmental faculties of 7 hungarian higher education institutes statements:

No. 01: The essence of the evolution is that the more powerful creatures drown out the weaker ones.

No. 02: Evolution evolves in the direction of human being.

No. 03: Man defeated nature.

No. 04: Man is superior to other organisms.

No. 05: The lion is the king of beasts because it is top predator.

No. 06: At the top of the food pyramid the most advanced creatures survive.

No. 07: The human and the monkey are relatives.

No. 08: The human and the flatworm are relatives.

No. 09: A cockroach cannot be lovable.

No. 10: Animals are only controlled by their instincts.

1 Explanation: by converting an original Likert scale we created a scoring system where the answers have got (transformed) values between one and five - and these formed average scores. The average value closer to number one indicates the more anthropocentric and the value closer to number five indicates the more ecocentric overweight standpoints. 
According to the research results (with evaluation and summarize of all statements) first-grade students generally showed more ecocentric manifestations (although not always with significant degree) of human superiority, the acceptance of evolutionary theory and question the usefulness of organisms. However, graduate students had more positive relationship with the kinship, the amiability, the unconditional acceptance of other organisms. It can be concluded that number of students during the academic period, reviewed some previously learned knowledge while they reconstructed and further formed their views (with significant emotional elements interwoven). But their self-reflections (in the present circumstances) take place without external interventions (i.e. without educational activities). In other words, the empirical results of this study point out that, graduate students are slightly better atusing their option of free thinking than freshly arrived students from public education who are accustomed to usually more fixed circumstances and they also become more empathic with other organisms. However, it also seems to be confirmed that the universities essentially do not play a role in environmental awareness raising - or very inefficiently - because the students' opinions and the trends of thought remain almost unchanged over the years, and absolutely do not move in the direction of scientific thinking.

\section{THE ANTHROPOCENTRIC ATTITUDES BASED CONCEPTUAL MODEL}

The table above shows that the trends of anthropocentric responses in the wide variety of issuessuggests the existence of a special structural system within environmental thinking. In other words, it is not a coincidence that the same students who have formed a very clearly outlined concept about evolution also have very similar thoughts about kinship issue terms, about functioning of the food chain, about hierarchies of certain groups of organisms, about issues of personality, behaviour, usefulness and about necessary environmental interventions - and of course vice versa. Considering the factors above the data shows clear correlations so the responses can be grouped, and these groups can be organized into a holistic system. So I succeeded in building a theoretical model that - based on the anthropocentric results - attempts to describe the main aspects of the human-centric thinking about nature (especially ecological) issues. In doing so, it became clear that environmental conceptions and misconceptions of students have significantly determined their environ-

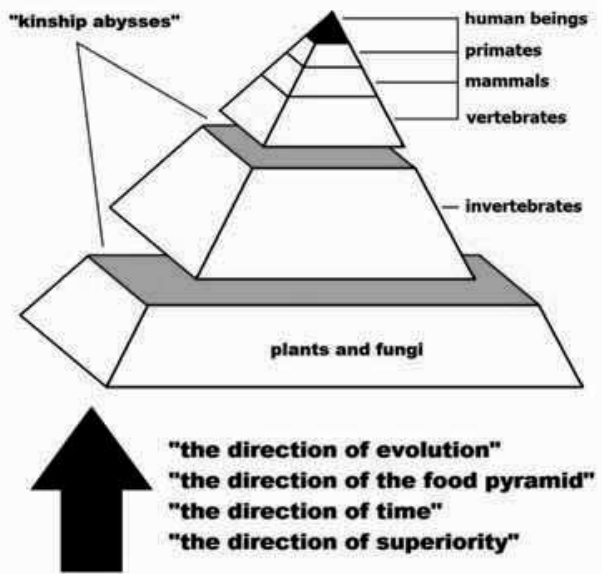

Figure 1. Environmental higher education students' views based model of the anthropocentric ecological thinking. 
mental attitudes. Prior knowledge and the highly adapted views (which are often very different from scientific views) have a huge role in the responses so they are not only emotional overweight attitudes.

Human-centric thinking in principle shows a logical structure and viable view of the world and this has enabled the creation of a model similar to a three-part pyramid. The spatiality of pyramid symbolizes the putative bio-mass and its specified orientation describes a hierarchical taxonomic system where the human stands on the top. The pyramid is based on layers (these are the imaginary taxonomic categories) including the kinship abysses (these empty layers symbolize that anthropocentric thinking does not accept the interconnections of all living creatures' genetic kinship - particularly between vertebrates and invertebrates, plants and fungi. The model also expresses that the evolution and relationships of eating set out orientations (directions) - meanwhile ignoring the changes that continue to this present day and the existence of parallel changes in the processes. Thus, while human beings constantly emphasize their views about superiority-inferiority relations, meanwhile, they can imagine a clear development path (which ends with the man as he is the pinnacle of evolution).

The ecological model of anthropocentrism may have been created in order to describe the environmental training of students formed (and very well-defined) groups of opinions, furthermore the students designated relatively clear direction-lines in their own thinking. These are grouped with evolution, the systematics and the nutritional relations that are clearly described as a developmental model and as if everything went one's way (and always inferior living beings move towards the superior living beings). The impacts of functionalism was noticeable in the decisions of ecological issues and strong susceptibilities to generalization and prioritization. The unique interpretations of environmental systems and processes caused the positive or negative environmental attitudes and usually the more ecocentric views caused more positive, the more anthropocentric views caused more negative attitudes in these issues.

\section{THE INHOMOGENEITY OF ANTHROPOCENTRISM}

Human-centric thinking is, of course, not really a unified world view, which is also confirmed by the results of empirical research. Thus, for example the manifestations of radicalism and the distances from scientific approaches were measured through attitudes. Various role perceptions are outlined based on the student's environmental approach. It was possible to categorize the specific person's own roles depending on the strength of anthropocentrism because the students categorized policies of wildlife in terms of the relationship between human and nature all the time.

"governing" role perception

The majority of students believe that the human is on the top of evolution, so if they believe in evolution as well, then by all means they give it a direction where the human stands on the upper end (or top). Typically they misinterpret taxonomy (in particular the levels of organization or the aspects of taxonomic), food 
"pyramids" (in fact the food chain), natural selection (which is usually a confused concept of evolution or a cruel evolution). They frame these concepts in terms of hierarchy. Perhaps they extrapolate their (socialization-based) hierarchical ideas on flora and fauna and think that this is how nature works.

"godhead" role perception

In addition to the above, if students deny kinship with flora and fauna, this in itself increases their anthropocentric perspective and breaks the scientific approach. Thus, they regard man as a sense of goodness (or demigod). They view humans as divine selected or a non-terrestrial origined creature - and the other living beings become biomass, servants, and resources.

"other" role perception

The students define, apply, or interpret some everyday concepts differently from the scientifically accepted norms. This role perception establishes a distance between human beings and other organisms via their properties. Personality, the ability to think, language, love, feeling, intelligence are characteristics specific to humans. This view holds that the human is the only creature who can think about the future and who is not simply an "instinct being". However, this role does not make the human a superior creature.

"ecological" role perception

According to this perspective, humans are part of nature and wildlife is not a hierarchical system whose regularity is non-anthropocentric. The focus is coexistence and harmony.

There are correlations between environmental literacy and attitudes, but their strength is very diverse and generally changes depending on the particular issues or topics raised. One factor's functioning is inconceivable without the other (for example the low ecological literacy level usually relates to high level of anthropocentrism), and the effects do not prevail alone. However, we see that higher education is primarily focused on the development of environmental literacy but does so rather inefficiently. One reason for this is the ignoring ofthe educational (didactic) tasks. Educational efforts are not prevented by anything per se, but to the present day there is a social and professional scientific debate about the trainability of environmental approach. While some proponents regard environmental education primarily as knowledge transfer, and consider it essential that the next generation needs to acquire advanced knowledge to solve the problems, others - although they too consider that natural science funds are important factors focus instead on human behaviour and responsibility to change environmental attitudes.

\section{INTERVENTION ALTERNATIVES}

To make environmental thinking sustainable, we should have begun a long time ago because reshaping human-centric thinking is a lengthy task. In addition, despite the previously pursued international initiatives (such as the Education for Sustainability International Decade which was published by the United Nations) and nation-states' policy measures, their thoroughness and effectiveness are highly questiona- 
ble (Brunold, 2006). In the meantime - if we just look at the anthropocentric thinking - changing this existing, highly adapted system is extremely complex and difficult. In particular, typically neither the legal environment, nor the institutional structure, nor the environmental and policy paradigms, nor the educational preparatory programs and executive professionals' competencies are assured.

We have to adapt to the current situation in some way, therefore we have to utilize today's opportunities while also laying the groundwork for long-term action. This can start with exploiting existing potential of cooperation between educational institutions (joint training agreements, joint actions, initiatives and actions), giving preference to environmental ethics in public education and higher education (development of norms), and institutional commitment to environmental matters. This should be augmented with leading by example of faculty leaders and academics.

The world's religions may also lend a hand. Using their direct influence on many people they can incorporate a spiritual level into environmental thinking, and with this they may partially fill the still gaping void in law and social activity (e.g. see book series edited by Tucker \& Grim, 1997-2004). Complementing law in the short term can help professionals' work: so far the observed exercises of rights were too technical, too much concentrated on solving the problems (Stone, 1997). Binding better to nature protection (by society and individuals) can be facilitated with the legal justifications and goals emphasized in legislation. Nature-oriented and people-oriented environmental approaches will always be in opposition to one another despite their conceptual parallels - because the interests and dissimilarities will never be merged in the conceptual space - but we can draw them closer to each other and sometimes form bridges between them (Hovardas, 2012).

A constructivist research of Crowe (2012) tries to figure out how to 'use' the religions through eco-spirituality for improving environmental approach and notes that essentially the attitudes showed no significant difference between control groups and experimental groups, but the spiritual approach alone is not a dead end in solving the problem - and this may be a relevant relation or indicator of a possible effectiveness of anthropocentric environmental awareness.

The system of social expectations should reflect the natural aspects as well, but to achieve this goal we have to correct the anthropocentric eco-views. The main condition of successful implementation is that we have to present to society the alternatives and society needs to accept ecocentrism. However, similar to the constructivist teaching methods, new conceptions should not only be simply new, but should be better and more useful when compared to existing views. Regarding content it can be said that in environmental training it can be an effective solution if during the teaching of professional subjects academics focus on their own territories, but carry out a significant self-examination: are their methods up to date, do they meet the requirements of sustainability in the curricula, and are they reliable examples? Do the tasks cover the concepts and corrections of stereotypes? Do they take into account students' prior knowledge and the strong presence of layman thinking? Do they pay due attention to careful monitoring and feedback? Do they take into account the multi- and interdisciplinary of curricula, the interfaces within the curricula?

The following processes are recommended for positive changes: 
- Updating and integrating the most important knowledge within the curriculum of public education;

- Review current curriculum;

- Adapt curriculum contents to students' sphere of interest using motivational tools;

- Harmonization of academics and knowledge used during the teaching process to achieve credibility;

- Concentrate on the main concepts during the whole educational process (in particular, the themes and issues of the relationship between people and wildlife);

- Meanwhile for curriculum planning and creation: rethink how they build upon each other; methodize the ecological sustainability knowledge in terms of the system and locate its new place in the curriculum.

The curriculum reform of basic subjects does not necessarily require concrete action within the specific topics but it needs at least the partial integration of the approaches and methodologies resulting from public education. One of these flagship applications is a model of environmental education by Palmer \& Neal (1994). It recommends taking into account the specifics of modern environmental public education with their problems and solutions while choosing themes, characteristics, examples, and methods based on these.

If it is possible, the environmental training in higher education should focus on the following areas:

- Taxonomy: need clarification of definitions with explanations (for example: correct placement of taxons; manage ambiguous terms as 'higher levels', 'superior animals', 'inferior organisms') and emphasize kinships.

- Evolutionary biology: need to clarify the exact theory of evolution, emphasize the proper use of associated concepts (for example: natural selection), highlighting the parallel changes in time.

- Ethology: need greater emphasis for parallels and human-animal kinships.

- Ecology: need to show ecological processes in more specific contexts, operations and proper placement in the curriculum.

- Hunting: need more explanation to clarify the concepts and terminology (for example: 'brute animals', 'harmful animals', 'mature stag animals') with ambiguity eliminate and emphasize nature-orientation ('ecocentric hunting').

- Nature and landscape: need nature-oriented description of conservation objectives, explanation with integration of environmental ethics, multi-faceted approach to certain problems (using more nature-based example in environmental impact assessment).

We also have to consider setting the anthropocentric and ecocentric models against each other in the curriculum - even within a lesson - to show the functioning of natural systems on the basis of this dichotomy to the students. This will ensure that their evolutionary, taxonomic, ecological and behavioural skills would develop and a change would come in the environmental perspectives and conceptions. However, it should be noted that there is still a long road to conceptual change, one that is filled with obstacles. The suggestions described above are likely to be only a partial solution. 


\section{REFERENCES}

Abel, D. C. (1989). Freud on Instinct and Morality. Albany: State University of New York Press.

Brunold, A. O. (2006). The United Nations decade of education for sustainable development, its consequences for international political education, and the concept of global learning.International Education Journal, 2006, 7, 3, 222-234.

Crowe, J. L. (2012). Transforming Environmental Attitudes and Behaviours through Eco-spirituality and Religion.International Electronic Journal of Environmental Education, 3, 1, 75-88.

Csapó, B. (2002, ed.). Az iskolai müveltség [Literacy in the school]. Osiris Kiadó, Budapest, 65.

Dyehouse, M., Weber, N. R., Fang, J., Harris, C. A., Tomory, A. \& Strobel, J. (2011).First-Year Engineering Students' Environmental Awareness and Conceptual Understanding through a Pilot Sustainable Development Module. American Society for Engineering Education, 1, 897-904.

Gould, S. J. (1996). Full House (in the United Kingdom: Life's Grandeur). New York, Harmony Books, Evolution, 51, 3, 1015-1020.

Havas, P. \& Varga, A. (1998). Általános és középiskolás diákok környezettel kapcsolatos attitűdjei és ismeretei. Összehasonlító vizsgálat a "Természettudományokkal Európán Keresztül" program hatékonyságáról [Environmental attitudes and knowledge of primary and secondary school students]. Comparative study on the effectiveness of the "Through the natural sciences in Europe" program, Science Across the World

Hovardas, T. (2012). A Critical Reading of Ecocentrism and Its Meta-Scientific Use of Ecology: Instrumental versus Emancipatory Approaches in Environmental Education and Ecology Education. Science \& Education, 34, 21, 1-17.

Kellert, S. R. (1976). Perceptions of animals in American society. Transactions of the North American Wildlife and Natural Resources Conference, 41, 533-546.

Lányi, A. (1999). Együttéléstan [Coexistence]. Liget Múhely Alapítvány, Budapest, 122.

Mérei, F. \& V. Binét, Á. (2006). Gyermeklélektan [Child Psychology]. Medicina Könyvkiadó Rt., Budapest, 15, 32-35.

Nevanpää, T. \& Law, N. (2006). Pupil's ecological reasoning with help of modelling tool. Proceeding Of The 2006 Conference On Interaction Design And Children, Tampere, Finland, 6, 41-44.

Palmer, J. \& Neal, P. (1994). The Handbook of Environmental Education. London and New York: Routledge.

Puk, T. \& Stibbards, A. (2011). Growth in ecological concept development and conceptual understanding in teacher education: The discerning teacher. International Journal of Environmental \& Science Education, 6, 3, 191-211.

Radnóti, K. (2009). Kutatási összefoglaló jelentés a felsőoktatásba belépő BSc hallgatók fizika és kémia tudásáról 2009 [Knowledge of first year students in physics and chemistry.Research Summary Report, 2009]. Budapest: ELTE TTK Fizikai Intézet, 6.

Rebolj, N. \& Devetak, I. (2013). 15 and 16 Years-Old Students' Understanding of Factors That Influence Water Pollution. Energy and Environment Research, 3, 1, 106-114.

Schirmacher, W. (1992). La technique de la vie ou: la pratique de la responsabilité. In: Poulain J. (Ed.), Penserapres Heidegger. (p. 226). Paris: L' Harmattan.

Stone, C. D. (1997). Should Trees Have Standing? - Toward Legal Rights for Natural Objects (1972). In: R. V. Percival \& D. C. Alevizatos (Eds.), Law and the environment (pp. 306-312). Philadelphia: Temple University Press.

Szántó, J. (1994). Attitüdök a környezettelés a környezetvédelemmel kapcsolatban a felnőtt magyar lakosság körében [Attitudes regarding the environment and the environment in the adult Hungarian population]. TARKI - ELTE Institute of Sociology, Budapest

Tamir, P. \& Zohar, A. (1991). Antropomorphism and teleology in reasoning about biological phenomena. Science Education, John Wiley \& Sons, 75, 1, 57-67.

Tucker, M. E.\& Grim, J.(Eds.) (1997-2004).World Religions and Ecology Series.Cambrige, MA: Harvard University Press, Vol. 1-10.

Varga, A. (2004). A környezeti nevelés pedagógiai, pszichológiai alapjai [Environmental education based on pedagogy and psychology]. PhD dissertation. Eötvös Loránd University, Graduate School of Education, 76-79.

Werth, A. J. (2013). An Evolutionary Focus Improves Students' Understanding of All Biology. Reports of the National Center for Science Education, 33. 3, 1-18. 